\title{
LEVELLING THE PLAYING FIELD: REDUCING BARRIERS TO MENTORING FOR WOMEN PROTÉGÉS IN THE SOUTH AFRICAN ORGANISATIONAL CONTEXT
}

\author{
KEVIN STONE \\ MELINDE COETZEE \\ Department of Industrial \& Organisational Psychology \\ University of South Africa
}

\begin{abstract}
The purpose of this study was to investigate the impediments to effective mentoring faced by women protégés at two South African organisations. The purposive sampling method was used to identify female employees who had participated as protégés in a mentoring relationship $(\mathrm{N}=17)$. Qualitative methods were used to collect and analyse data on the respondents' experiences of the mentoring relationship. The findings indicated numerous barriers to mentoring for women. A basic taxonomy of recommendations for reducing these barriers in the workplace is recommended.
\end{abstract}

\section{OPSOMMING}

Die doel met hierdie studie was om die hindernisse wat deur vroue protégés in twee Suid-Afrikaanse organisasies ervaar word ten opsigte van doeltreffende hulp en leiding (mentoring), te ondersoek. 'n Doelmatigheidsteekproefneming is aangewend om vroulike werknemers wat deel van 'n mentorverhouding was, te identifiseer $(\mathrm{N}=17)$. Kwalitatiewe metodes is benut om data oor die respondente se ervaring van die mentorverhouding te versamel en te ontleed. Die bevindinge dui op aansienlike hindernisse tot die mentor van vroue. 'n Basiese taksonomie van aanbevelings vir die vermindering van hierdie hindernisse in die werkplek word aanbeveel.

The potential benefits of an organisational mentoring programme that is soundly designed, correctly implemented and well managed are numerous (Clawson, 1979; Clutterbuck, 2001; Clutterbuck \& Ragins, 2002; Coetzee \& Stone, 2004; Klasen \& Clutterbuck, 2002; Kram, 1985a; 1985b; Scandura, Tejeda, Werther \& Lankau, 1996; Tabbron, Macaulay \& Cook, 1997). It is considered an important training and development tool, both in the academic literature (Hunt \& Michael, 1983; Kram, 1985a) and in practice.

While literature on mentoring interventions in the organisational context is plentiful (Arnold, 1997; Caldwell \& Carter, 1993; Coetzee \& Stone, 2004; Clutterbuck, 2001; Clutterbuck \& Ragins, 2002; Forret, Turban \& Dougherty, 1996; Galbraith \& Cohen, 1995; Greenhaus, Callanan \& Godshalk, 2001; Klasen \& Clutterbuck, 2002; Kram, 1985a; Kram \& Bragar, 1992; Veale \& Wachtel, 1996), and the issues facing women in mentoring have also received attention (Akande, 1994; Clutterbuck \& Ragins, 2002; Kram, 1985a; Hurley \& Fagenson-Eland, 1996; Linehan \& Walsh, 1999; Okanlawon, 1994; Ragins \& Cotton, 1996; Thomas, 2001), few studies have focused specifically on the barriers to mentoring faced by women in the South African organisational context. Given the increased focus on organisational compliance with labour legislation such as the Employment Equity Act, 55 of 1998, and the escalating proportion of women joining the workforce, the lack of attention to this issue could be considered an urgent concern.

Furthermore it could be argued that the existing literature dealing with the barriers faced by women in mentoring are not only plentiful, they are also problem-focused rather than solution-focused. The literature primarily emphasises the challenges faced by women, but it contains very few practical recommendations to aid the reduction of the barriers to mentoring experienced by women in the South African organisational context

Requests for copies should be addressed to: M Coetzee, coetzm1@unisa.ac.za

\section{Women and mentoring}

The directions taken in the world of work and in staff development in particular have unquestionably been the result of continuous, rapid change (Coetzee \& Stone, 2004; Finkelstein, Allen \& Rhoton, 2003; Handy, 1994; Jossi, 1997; Schreuder \& Theron, 2001). Viewed within a systems context (Cascio, 1998), changing societal and political norms have led to changes in the composition of the workforce. The workforce now includes greater numbers of women, the average age of workers have increased, and there is more cultural and ethnic variability (Arnold, 1997; Grobler, Warnich, Carrell, Elbert \& Hatfield, 2002), countering the previous image of predominantly homogenous organisations. In the South African context the provisions of the Employment Equity Act,. 55 of 1998, have placed particular emphasis on correcting demographic imbalances in the workplace. Every organisation in South Africa should regard the development of historically disadvantaged staff, which specifically includes women, as a high priority (Grobler et al., 2002). For many organisations, the implementation of mentoring has proven to be a useful mechanism for advancing workplace diversity through the development of female employees (amongst others) to ensure legislative compliance and to redress past inequalities (Greenhaus et al, 2001; Schreuder \& Theron, 2001).

The concept of mentoring is not new. Although it is closely related to craft apprenticeship schemes of the past (Wilbur, 1987) and despite numerous different approaches to the definition thereof (Armstrong, Allinson \& Hayes, 2002; Clutterbuck \& Lane, 2005), it is in many ways simply a modern term for a time-honoured concept (Hagenow \& McCrea, 1994; Clutterbuck \& Sweeney, 2003). Clutterbuck and Sweeney $(2003, \mathrm{p} 4)$ define the mentoring process in a contemporary organisational context as "off-line help by one person to another in making significant transitions in knowledge, work or thinking". Mentoring is viewed as a developmental, caring, sharing, helping relationship where one person invests time, know-how and effort to increase and improve another person's growth, knowledge and skills (Klasen \& Clutterbuck, 2002). 
Organisations are increasingly turning to mentoring programmes as a vehicle for creating opportunities for open communication among employees and for assimilating newcomers into the institutional culture (Clutterbuck, 2004; Clutterbuck \& Ragins, 2002; Parsloe \& Wray, 2000; Webb, 1995). From an individual perspective, having a mentor has been linked to mobility and career advancement (Baruch, 2004; Clawson, 1979; Clutterbuck, 2001; Clutterbuck, 2004; Jennings, 1971; Kram, 1985a; 1985b; Phillips-Jones, 1982; Scandura, 1992; Stumpf \& London, 1981). In the race to the top, mentors can make the difference between getting on the inside track and trailing the field (Dreher \& Ash, 1990; Fagenson, 1989; Scandura \& Williams, 2002; Scandura \& Hamilton, 2002; Whitely, Dougherty \& Dreher, 1991). A number of studies indicate that persons who have received extensive mentoring report that they are promoted more often, earn higher incomes and are more satisfied with pay and benefits (Akande, 1994; Hall \& Kahn, 2002; Parsloe \& Wray, 2000; Scandura \& Hamilton, 2002). So too, research consistently indicates that mentoring is related to a variety of positive work outcomes, including higher degrees of career and organisational commitment, recognition, satisfaction, career mobility and compensation (Fagenson, 1989; Greenhaus et al, 2001; Klasen \& Clutterbuck, 2002; Whitely et al, 1991).

Mentoring becomes especially important in a diverse (multicultural or multigender) environment where nonperformance-related factors can block career progress (Clutterbuck \& Ragins, 2002; Finkelstein et al, 2003; Gordon, 1993). Women, in particular, are told that mentors are essential for overcoming gender-related barriers to advancement (Burke \& McKeen, 1990; Noe, 1988; Ragins, 1989;Thomas, 2001). Studies have consistently shown that a significantly high proportion of women with successful careers have received encouragement and support from mentors (Arnold \& Davidson, 1990; Hennig \& Jardim, 1978; Ragins, 1997; Ragins \& Cotton, 1991).

Paradoxically, mentoring for women has not occurred to a sufficient degree in the workplace, and female employees often find themselves restrained by a number of barriers (Akande, 1994; Clutterbuck \& Ragins, 2002). The following barriers have been identified through various studies: women lack access to networks within organisations; women may be viewed as tokens who cannot reach top management; and misconceptions about women's abilities to manage may reduce the view of their performances. In addition, women may be seen as having been socialised to develop personalities alien to management success; cross-gender mentoring relationships may be viewed as taboo; and women may rely on ineffective sources of power, thereby reducing their success (Clutterbuck \& Ragins, 2002; Kram, 1985a; Linehan \& Walsh, 1999; Morrison, 1988; Noe, 1986; 1988; Ragins \& Cotton, 1996; Robbins, 1993).

Recurring problems faced by women entering and sustaining mentoring relationships include the absence of women in influential positions who can be effective mentors and role models, marital disruption, and the possibility of sexual undertones in cross-gender mentoring which may constrain the relationship (Arnold, 1997; Clutterbuck \& Ragins, 2002; Greenhaus et al, 2001; Thomas, 2001). Moreover, although mentoring relationships may prove to be crucial for women's strategic decision-making in organisations, women are significantly less likely than men to develop these relationships (Linehan \& Walsh, 1999; Nieva \& Gutek, 1981).

Based on such findings, there can be little doubt that women are handicapped in the race to enter and sustain mentoring initiatives. This has been confirmed by a marked proliferation of training and development programmes aimed at helping female employees develop mentoring relationships (Burke \& McKeen, 1989; Chao, Walz \& Gardner, 1992). However, these programmes are often instituted without a clear understanding of the barriers to mentoring that women may encounter. In reality, organisations are spending considerable sums of money on programmes to remove barriers without a clear understanding of what these barriers actually are (Clutterbuck \& Ragins, 2002; Ragins \& Cotton, 1996). In a diverse workplace such as the typical South African organisation, the successful development and advancement of women can spell the difference between strategically aligned, equitable workforce practices and a definitive lack of legislative compliance (Grobler et al, 2002).

Viewed against the backdrop of the challenges and complexities regarding the mentoring of women, the implementation of mentoring targeted at female employees may require interventions that take into account the unique barriers faced by South African women who attempt to enter and sustain mentoring relationships. The objective of this study is to investigate women's perceptions of the impediments to effective mentoring in the South African organisational context. More specifically, the research aims to answer the following research questions:

- How effectively does the organisation focus on the development of women?

- What do female mentees perceive as the major barriers or problems they face in participating in a mentoring relationship?

\section{RESEARCH DESIGN}

\section{Research approach}

A qualitative approach was decided upon, since as this approach is specifically suitable when the research takes place in a natural setting (Silverman, 2000). Qualitative research attempts to make sense of and interpret constructs and phenomena in terms of the meanings that people ascribe to them, thus seeking to give meaning to social experience (Denzin \& Lincoln, 1994). Merriam (2002) also recommends that a qualitative approach be used when the research objectives are exploratory and descriptive. Silverman (2000) also asserts that qualitative studies are commonly believed to provide a deeper understanding of the phenomenon being investigated. Since the research questions pertain to understanding and describing a particular phenomenon about which very little is known, the qualitative approach appeared to be the most suitable for gaining insight about respondents' perceptions of the barriers females experience regarding sustaining an effective mentoring relationship in the South African organisational context (Creswell, 1994).

This study was therefore conducted within a qualitative paradigm and the grounded theory method was used to develop an inductively derived theory (Strauss \& Corbin, 1990). This method enabled the researcher to study the phenomenon (barriers to mentoring) within its context and facilitated the systematic generation of theoretical principles from, and grounded in, the data regarding the respondents' expectations of and viewpoints on the impediments to effective mentoring as experienced by female mentees.

\section{Respondents}

Two South African information technology (IT) organisations were used as case study institutions for this study. The population consisted of 375 IT employees - 235 from Organisation A, and 140 from Organisation B. In Organisation A, $24 \%$ of the employees were female and in Organisation B $41 \%$ were female. In both organisations women occupy less than $15 \%$ of senior management positions.

A non-random, purposive sampling strategy (Huysamen, 1994) was adopted to identify females who had participated as a 
protégé in a mentoring relationship during the previous year. This process identified 17 female mentees $(\mathrm{N}=17)$ from the two case study organisations who agreed to participate in the study. The sample constituted 1 Coloured, 10 White, 3 Indian, and 3 African females. Twelve of the females were matched with a male mentor and five of the females were matched with a female mentor. The 10 White mentees were all matched with White mentors, whilst the 1 Coloured, 1 of the 3 Indian, and 2 of the African female mentees were matched with White mentors. Two Indian females were matched with an Indian mentor whilst 1 African mentee was matched with an African mentor. The mean age of the mentors was 36 and those of the mentees 27 years.

\section{Method of data gathering}

The study was conducted within a qualitative research paradigm. The qualitative data collection technique in this study included a semi-structured qualitative interview with each participant. The duration of each interview was approximately 25 minutes and respondents were asked to answer two open-ended questions, namely:

- How effectively does your organisation focus on the development of women?

- As a female protégé, what (if any) were the major barriers or problems you faced in participating in a mentoring relationship?

\section{Procedure}

The women were approached telephonically or via e-mail and invited to participate in the study. The nature of the study was explained and anonymity guaranteed. Participants were offered the opportunity to peruse and comment on the transcripts of interviews once they became available.

\section{Data analysis}

The data was analysed with the aid of a qualitative content analysis process (Berg, 2001). By the end of the data collection and transcription process, a preliminary understanding of the data had been obtained. Thereafter, underlying themes were induced, which indicated organising principles that underscored the data. This was followed by a coding process, during which sections of the data were labelled as relevant to one or more of the identified themes. In addition, the frequency of responses to questions and the occurrence of themes were analysed in a quantitative manner (Berg, 2001). In conclusion, the themes were interpreted in the light of existing literature on the topic, which made meaningful interpretation of the results possible.

\section{RESULTS}

The main findings indicated that White male mentors were still predominant. The female mentees indicated that limited attention was given to the development of women. The crossgender composition seemed to create barriers that made it difficult for the respondents to participate effectively in the mentoring relationship.

The racial homogeneity of employees with the necessary expertise to mentor others in the workplace successfully (Ragins, 1995) was reflected in the sample It is also interesting to note that only black (African, Coloured, Indian) individuals had participated in cross-cultural mentoring relationships, while all the white protégés were matched to white mentors. These findings collectively confirm the relatively high representation within these case study organisations of white males in senior positions that lend themselves to the mentoring of developing female employees. Of the 17 women who participated in the study, 12 indicated that they had been in a cross-gender mentoring relationship (i.e. with male mentors), confirming the general finding that women are more likely to enter workplace mentoring relationships with male mentors (Arnold, 1997; Clutterbuck \& Ragins, 2002). Kram's (1985a) proposition that mentors are generally older than their protégés was reflected in the current sample, with the participating protégé's reportedly being on average almost 7 years younger than their male mentors, and 2 years younger than their female mentors.

\section{Effectiveness of the development of women in} organisational context

The majority of respondents felt that their organisation was not doing enough to focus specifically on the development and advancement of women. According to some respondents "prejudice" and "discrimination", although outlawed by South Africa's Employment Equity Act, 55 of 1998, were still prevalent, and affected the development of women in the case study organisations negatively. A common concern was the "lack of senior management support" for initiatives aimed particularly at developing women, and some respondents felt that their organisation was "not accepting its responsibility" to foster the development of women in the workplace (Greenhaus et al, 2001). One participant summarised her perception of the matter by stating that her organisation's "lack of commitment to the advancement of women is clearly mirrored by its lack of female management representation".

Numerous respondents interpreted the lack of formal programmes aimed specifically at the development of women as a lack of management support for the process of developing female employees. More often than not, this led to the perception that efforts at furthering their careers in the organisation (e.g. through a mentoring relationship) would be "futile". Respondents indicated that female protégés aspiring to management positions were often pressured to adopt the traditional male managerial skills and attitudes (Linehan \& Walsh, 1999; Okanlawon, 1994).

\section{Perceptions of the major barriers to participating in the mentoring relationship}

In response to the question about the barriers or problems that made it difficult for the respondents to participate in a mentoring relationship within their respective organisations, the majority of them indicated that the participation of women in workplace developmental relationships was fraught with difficulty. Most respondents indicated that they have fewer formal and informal opportunities to obtain mentors than their male counterparts, a view supported by Okanlawon (1994). Research confirms that women are less likely than their male counterparts to report having had mentoring relationships (Clutterbuck \& Ragins, 2002; Dreher \& Cox, 1996). It was indicated that women who occupied high-profile positions often resisted mentoring junior female employees. These women seemed to prefer not to have their actions construed by male colleagues as a sign of weakness or to avoid other females who could threaten their positions. This so-called "Queen Bee Syndrome" (Okanlawon, 1994; Powell, 1988) further exacerbated the difficulties experienced by women wishing to enter mentoring relationships.

Two interviewees referred to the "glass ceiling" concept. They indicated that women could not move into top management positions because of discrimination in the workplace, the inability of women to penetrate the "old boys' network" and the tendency of executives to promote others like themselves (Larwood \& Gutek, 1987; Morrison \& Von Glinow, 1988). It was felt that this negated the purpose of mentoring relationships and relegated such initiatives to the equivalent of "windowdressing" or tokenism (Greenhaus et al, 2001) to achieve gender equity targets.

Generally, the respondents recounted difficulty and reluctance in situations where they had to initiate mentoring 
relationships. The most common reason for this was that they felt their approach could be "misinterpreted as a sexual advance" by potential male mentors (Clawson \& Kram, 1984; Clutterbuck \& Ragins, 2002; Galbraith \& Cohen, 1995; Linehan \& Walsh, 1999; Ragins, 1989). One participant indicated that she had been turned down by a potential male mentor who feared the possibility of being charged with sexual harassment should he unwittingly "act out of his place", indicating unclear boundaries in this regard (Hurley \& Fagenson-Eland, 1996; Reynolds, 1993). Respondents expressed the opinion that issues of increasing intimacy and sexual tension inherent to cross-gender relationships (Kram, 1985a) made it difficult to establish rapport and added stress to the mentoring relationship. At times these issues even resulted in the demise of the mentoring relationship (Arnold, 1997).

The respondents indicated that there were few suitable female mentors available in their organisations. The subsequent crossgender mentoring relationships in some cases resulted in a loss of credibility as colleagues apparently perceived an element of romantic involvement between mentor and protégé (Bowen, 1985, Ragins \& Cotton, 1996). Another complication of cross-gender mentoring relationships common to a traditionally male-dominated workplace was that protégés found it difficult to identify with the role model or mentor. Women in the early years of their career often face development dilemmas that are unique to females in a maledominated organisational context (Baker-Miller, 1976; Clutterbuck \& Ragins, 2002; Kanter, 1977; Missirian, 1982). As one respondent claimed, "male mentors simply don't understand what it means to be a female protégé in the workplace today".

Respondents suggested that employees who were very assertive in their attempts to initiate a mentoring relationship were often seen as threatening (especially by potential male mentors), primarily as the result of traditional or "legacy" sex-role expectations (Clutterbuck \& Ragins, 2002; Maccoby \& Jacklin, 1974) still prevalent in the South African workplace. While men were expected to seek a mentor actively, participants felt that women were expected to wait until they were chosen. Relatively poor representation of women in top management (Couric, 1989; Linehan \& Walsh, 1999; Ragins \& Cotton, 1991; Ragins \& Scandura, 1994) meant that senior management rarely understood the particular issues faced by women hoping to further their careers through mechanisms such as mentoring. It was also felt that this "reduced the potential pool of suitable female mentors". One respondent mentioned a "vicious cycle" in the workplace. Her perception was that although women were in need of mentors, their relative lack of experience often made it difficult for them to obtain mentors because they did not know how mentoring works or how to approach it. This view is confirmed by Ragins and Cotton (1996).

Women in both case study organisations generally occupied low-level staff positions (Clutterbuck \& Ragins, 2002; Ragins \& Sundstrom, 1989), resulting in a reduced likelihood that they would be afforded the opportunity to demonstrate involvement in key decision-making tasks that could give rise to mentoring relationships (Kram, 1985a; Reich, 1985). So too, a number of respondents felt that they lacked access to "male-dominated networks" and therefore had less opportunity to penetrate the dominant coalition (Brass, 1985; Clutterbuck \& Ragins, 2002; Dreher \& Dougherty, 199). Either by design or by default, women were often excluded from the informal meetings and networks where mentorprotégé relationships were regularly initiated (Greenhaus et al, 2001). Table 1 gives an overview of the key barriers reported by the respondents.
TABLE 1

\section{BARRIERS TO MENTORING FOR WOMEN PROTÉGÉS}

Lack of opportunities to obtain mentors

Lack of management support

Exclusion from male-dominated networks

Poor representation of women in top management

Prejudice/discrimination against women

Misinterpretation of sexual boundaries in cross-gender relationships

Pressure to adapt traditional male managerial attitudes \& values

Lack of suitable female mentors

Legacy sex-role expectations

Difficulty relating to male role modelsIssues of intimacy \& sexual tension in cross-gender relationships

Lack of experience in forming and sustaining mentoring relationships Lack of willingness among of senior females to mentor their junior counterparts

\section{DISCUSSION}

The results of the present study have a number of practical implications for organisations seeking to promote the development and advancement of women through mentoring relationships. The elimination of all these barriers may not be possible (Clutterbuck \& Ragins, 2002; Hurley \& Fagenson-Eland, 1996), but organisations that study the impediments that women face in initiating and sustaining mentoring relationships, and work on solutions which will alleviate or reduce those barriers, are more likely to sustain productive, effective mentoring initiatives (Klasen \& Clutterbuck, 2002; Lobel, 1993).

Based on the findings of this study, as well as salient contributions to the field of women in mentoring outlined elsewhere in this article, a taxonomy of interventions aimed at reducing the problems faced by female employees in developmental mentoring relationships is proposed. A summary of the taxonomy - divided into initiatory or access barriers, cross-gender barriers and equity barriers - is presented in Figure 1 , with further elaboration in the discussion thereafter.

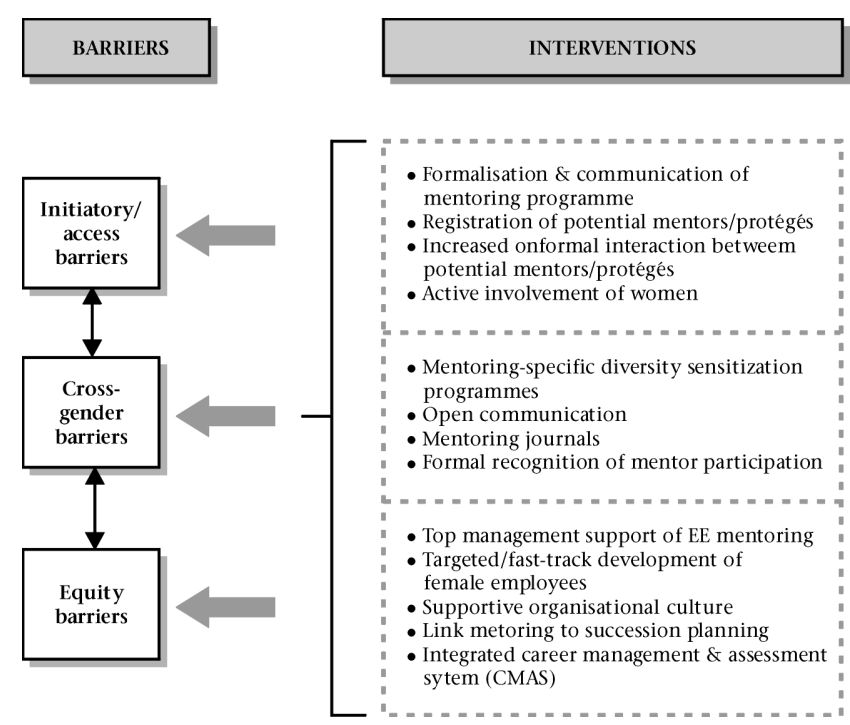

Figure 1 Proposed taxonomy of interventions for reducing barriers faced by women protégés in mentoring

Reducing initiatory or access barriers

- The establishment of formal mentoring programmes in organisations, as opposed to ad hoc or informal mentoring, will help improve access to mentors (Klasen \& Clutterbuck, 2002; Ragins \& Cotton, 1996). It may also help alleviate 
protégés' fear of approaching male mentors and male mentors' fear of seeking out female protégés (Hurley \& Fagenson-Eland, 1996). These programmes (and their formal communication) will also help alleviate rumours about women who initiate mentoring relationships with men for sexual reasons, because the protégés could be assigned mentors by the organisation (Lewis \& Fagenson, 1995) under the auspices of a formal development programme.

- A formal register of potential mentors and protégés may simplify the process of gaining access to suitable partnerships in mentoring relationships. It may also reduce the stigma attached to cross-gender developmental partnerships.

- Human resource staff and organisations should increase the number of opportunities for women to meet potential mentors on an informal basis (Klasen \& Clutterbuck, 2002; Ragins \& Cotton, 1996). This may be accomplished by breaking down barriers to informal networking, for example by sponsoring social interaction between potential mentors and protégés.

\section{Reducing cross-gender barriers}

- Training programmes can be developed for potential female protégés and their mentors (Ragins \& Cotton, 1996). These programmes could be integrated with diversity efforts (Ragins, 1995), and could examine and alleviate sexual concerns in cross-gender relationships. They could also determine how gender-role stereotypes influence opinions about who has responsibility for initiating mentoring relationships. Ragins and Cotton (1996) further suggest that women who have successfully acted as mentors and role models be used in these training sessions. The training should also explicitly deal with the dangers of sexualising the mentoring relationship (Mainiero, 1989; Wilson \& Elman, 1990) by facilitating an understanding of the differences between sexual harassment, nonsexual psychologically intimate relationships, and sexually intimate relationships.

- The mentoring process should be as open and transparent as possible. This would help eliminate negative perceptions of women in mentoring, and could include specific guidelines aimed at eliminating problems with sexuality and intimacy in cross-gender mentoring relationships (Hurley \& FagensonEland, 1996).

- Hurley and Fagenson-Eland (1996) suggest that mentors and protégés keep mentoring journals to help them keep track of any problems that develop, and to enable management to facilitate the smooth running of mentoring programmes.

- Ragins and Cotton (1996) suggest that the number of potential female mentors could be increased by formally recognising mentoring activities in performance appraisals and salary decisions. By making the benefits greater than the costs, organisations can promote the development of female mentors and circumvent many of the barriers women face in developing cross-gender mentoring relationships.

\section{Reducing equity barriers}

- Top management must, as a matter of critical urgency, demonstrate their support of mentoring programmes (Catalyst, 1993; Clutterbuck \& Klasen, 2002). By committing to the advancement of women through policies, communication and overt action, both potential protégés and mentors would be more likely to initiate productive mentoring relationships.

- The targeted development of women is strongly opposed by some (Harlan \& Weiss, 1980) who say it merely highlights the perceived differences between men and women in the workplace. Yet research has proven that it is less threatening and that it enables women to overcome paternalistic workplace domination (Langrish, 1980; Makin, Cooper \& Cox, 1989). In the South African context where redress of past gender imbalances in the workplace is a priority (Employment Equity Act, 55 of 1998), a careful balance should be struck between training females along their male counterparts to increase their knowledge and experience, and educating male employees so that they become aware of the barriers women face in the organisation. Fast-track development programmes for women are well-known components of employment equity programmes in the South African context. If these are implemented and managed properly, they may help reduce some of the barriers faced by women in mentoring relationships.

- If potential minority mentors are identified in a wellplanned manner and if the development of these individuals' mentoring skills is prioritised, the gender and cultural heterogeneity of the pool of available mentors could improve.

- Organisations that regard the successful mentoring of women as important may need to reconsider their organisational culture. Many values held and assumptions made within a Western, male construct may not be appropriate and, instead of promoting multiple perspectives, may lead to mentoring that aims for homogenisation or conformity to one viewpoint (Clutterbuck \& Ragins, 2002; Galbraith \& Cohen, 1995). Moreover, the culture of an organisation significantly affects the extent to which differences in demographics will interfere with the establishment of development alliances (Kram, 1985a).

- Dreher and Dougherty (1997) proposed the design and establishment of an integrated Career Management and Assessment System (CMAS) that incorporates numerous career management initiatives. Such a CMAS would serve as a substitute for career mentoring and curb the oftenlimiting effect of gender in mentoring relationships. This may be a feasible solution for South African organisations seeking to reduce these and other equityrelated imbalances to ensure legislative compliance and fair personnel practices.

In conclusion, this study provided insight into the perceptions of women who participated in mentoring programmes at two case study organisations in South Africa. The results of the study were integrated with contributions from topical literature on the barriers faced by women who want to participate in mentoring relationships, culminating in the proposal of a brief taxonomy of potential mechanisms to reduce such barriers in the South African organisation.

A limitation of this sampling strategy is that the findings of the study only apply to women in the sample, and therefore cannot necessarily be assumed to be applicable to all female protégés in South African mentoring relationships. Future research on the topic of reducing the barriers faced by women in mentoring could possibly focus on the utility of the recommended initiatives in the South African workplace. It could also include a detailed exploration of the specific complexities surrounding women in developmental relationships that are simultaneously cross-gender and cross-cultural.

There can be no doubt that mentoring adds immense value to the development of women in particular and effective career management in general (Arnold, 1997, Baruch, 2002) in the South African context. However, organisations will have to align themselves strategically to make the successful mentoring of women possible. Organisations need to develop a vision of mentoring that emphasises the acceptance of differences that enrich their worldview and ultimately transform mentoring practices to make them congruent with a diverse South African society (Galbraith \& Cohen, 1995).

Organisations that institute mechanisms to address women's concerns regarding mentoring will reap the full benefits of mentoring in the South African organisational context. 


\section{REFERENCES}

Akande, A. (1994). The glass ceiling: women and mentoring in management and business. Employee Counselling Today, $6(1), 21-28$.

Armstrong, C.W., Allinson, C.W. \& Hayes, J. (2002). Formal mentoring systems: the effects of mentor/protégé cognitive styles on the mentoring process. Journal of Management Studies, 39 (8), 1111-1137.

Arnold, J. (1997). Managing careers into the $21^{\text {st }}$ century. London: Paul Chapman.

Arnold, V. \& Davidson, M.J. (1990). Adopt a mentor - the way ahead for women managers? Women in Management Review and Abstracts, 5 (1), 10-18.

Baker-Miller, J. (1976). Towards a new psychology of women. Boston: Beacon Press.Baruch, Y. (2002). Career systems in transition: a normative model for organisational career practices. Personnel Review, 32 (2), 231-251.

Baruch, Y. (2004). Transforming careers: from linear to multidirectional career paths: organisational and individual perspectives. Career Development International, 9 (1), 58-73.

Berg, B.L. (2001). Qualitative research methods for the social sciences. Boston: Allyn \& Bacon.

Bowen, D.D. (1985). Were men meant to mentor women? Training and Development Journal, 39 (2), 31-34.

Brass, D.J. (1985). Men's and women's networks: a study of interaction patterns and influence in an organisation. Academy of Management Journal, 28, 327-343.

Burke, R.J. \& McKeen, C.A. (1989). Developing formal mentoring programmes in organisations. Business Quarterly, 53 (3), 76-99.

Burke, R.J. \& McKeen, C.A. (1990). Mentoring in organisations: implications for women. Journal of Business Ethics, 9, 317-332.

Caldwell, B.J. \& Carter, E.M.A. (1993). The return of the mentor: strategies for workplace learning. London: Falmer.

Cascio, W.F. (1998). Applied psychology in human resource management (5th ed.). Upper Saddle River: Prentice Hall.

Catalyst, C. (1993). Mentoring: A guide to corporate programs and practices. New York, NY: Catalyst.

Chao, G.T., Walz, P.M. \& Gardner, P.D. (1992). Formal and informal mentorships: a comparison on mentoring functions and contrast with non-mentored counterparts. Personnel Psychology, 45, 619-636.

Clawson, J.G. \& Kram, K.E. (1984). Managing cross-gender mentoring. Business Horizons, 27 (3), 22-32.

Clawson, J.G. (1979). Superior-subordinate relationships for managerial development. Unpublished doctoral dissertation. Boston, Harvard Business School, Boston, MA.

Clawson, J.G. (1980). Mentoring in managerial careers. In C.B. Derr (ed.) Work, Family and the Career. New York: Praeger.

Clutterbuck, D. (1993). Everyone needs a mentor: fostering talent at work (2nd ed.). London: Institute of Personnel Management.

Clutterbuck, D. (2001). Everyone needs a mentor: fostering talent at work. London: CIPD.

Clutterbuck, D. (2004). The situational mentor. London: Gower.

Clutterbuck, D. \& Ragins, B.R. (2002). Mentoring and diversity: an international perspective. Johannesburg: ButterworthHeinemann.

Clutterbuck, D. \& Sweeney, J. (2003). Coaching and mentoring. Burnham: Clutterbuck \& Associates.

Coetzee, M. \& Stone, K. (2004). Learner support: toward learning and development. Knowres: Randburg.

Couric, E. (1989). Women in the large firms: a high price of admission? National Law Journal, December, 2-12.

Coyle, A. (1989). Women in management: a suitable case for treatment. Feminist Review, 31, Spring.

Creswell, J.W. (1994). Research design: qualitative and quantitative approaches. California: Sage Publications.

Denzin, N.K. \& Lincoln, Y.S. (1994). Handbook of qualitative research. Thousand Oaks, CalifCA: Sage.
Dreher, G.F. \& Ash, R.A. (1990). A comparitive study of mentoring among men and women in managerial, professional, and technical positions. Journal of Applied Psychology, 75, 539-543.

Dreher, G.F. \& Cox, T.H. (1996). Race, gender, and opportunity: a study of compensation attainment and the establishment of mentoring relationships. Journal of Applied Psychology, 81, 297-308.

Employment Equity Act. (1998). No. 55 of 1998. Pretoria: Government Printers.

Fagenson, E.A. (1989). The mentor advantage: perceived career/job experiences of protégés vs non-protégés. Journal of Organisational Behaviour, 10, 309-320.

Finkelstein, L.M., Allen, T.D., \& Rhoton, L.A. (2003). An examination of the role of age in mentoring relationships. Group \& Organisation management, 28 (2), 249-281.

Forret, M.L., Turban, D.B. \& Dougherty, T.W. (1996). Issues facing orgainzations when implementing formal mentoring programmes. Leadership and Organisation Development Journal, 17 (3), 27-30.

Galbraith, M.W. \& Cohen, N.H. (1995). Mentoring: new strategies and challenges. San Francisco: Jossey-Bass.

Gordon, J. (1993). Organisational behaviour. Boston, MA: Allyn \& Bacon.

Greenhaus, J.H., Callanan, G.A. \& Godshalk, V.M. (2001). Career management. New York: Dryden.

Grobler, P.A., Warnich, S., Carrell, M.R., Elbert, N.F. \& Hatfield, R.D. (2002). Human resource management in South Africa. Canada: Thomson.

Hagenow, N.R. \& McCrea, M.A. (1994). A mentoring relationship. Nursing Management, 251 (12), 42-43.

Hall, D.T. \& Kahn, W.A. (2002). Developmental relationships at work: A learning perspective. In C.L. Cooper \& R.J. Burke (Eds.). The new world of work: Challenges and opportunities, 49-74. Oxford: Blackwell.

Handy, C. (1994). The empty raincoat. London: Hutchinson.

Hansman, C.A. (1998). Mentoring and women's career development. In L.L. Bierema (Ed.). Women's career development across the lifespan: insights and strategies for women, organisations and adult educators, 63-73. San Francisco: Jossey-Bass.

Harlan, A. \& Weiss, C. (1980). Moving up: women in managerial careers. Third progress report. Welsley, MA: Welsley Centre for Research on Women.

Hennig, M. \& Jardim, A. (1978). The managerial woman. London: Marion Boyards.

Hunt, D.M. \& Michael, C. (1983). Mentorship: a career training and development tool. Academy of Management Review, 8 (3), 475-485.

Hurley, A.E. \& Fagenson-Eland, E.A. (1996). Challenges in cross-gender mentoring relationships: psychological intimacy, myths, rumours, innuendoes and sexual harassment. Leadership \& Organisation Development Journal, 17 (3), 42-49.

Huysamen, G.K. (1994). Methodology for the social and behavioural sciences. Halfwayhouse: Southern.

Jennings, E.E. (1971). Routes to the executive suite. New York, NY: McGraw-Hill.

Jossi, F. (1997). Mentoring in changing times. Training, 34, 50-53.

Kanter, R.M. (1977). Men and women of the corporation. New York, NY: Basic Books.

Klasen, N. \& Clutterbuck, D. (2002). Implementing Mentoring Schemes: A Practical Guide to Successful Programs. London: Butterworth-Heinemann.

Kram, K.E. (1985a). Mentoring at work. Glenview, IL: Scott Foresman.

Kram, K.E. (1985b). Improving the mentoring process. Training \& Development Journal, 44, 40-43.

Kram, K.E. \& Bragar, M. (1992). Development through mentoring: a strategic approach. In D. Montross and C. Shinkman (Eds.). Career development: theory and practice. Springfield, IL: Thomas Press. 
Langrish, S. (1980). Single sex management training - a personal view. Women \& Training News, 1, 3-4.

Larwood, L. \& Gutek, B.A. (1987). Working toward a theory of women's career development. In Gutek, B.A. \& Larwood, L. (Eds). Women's career development. Newbury Park, CA: Sage.

Lewis, A.E. \& Fagenson, E.A. (1995). Strategies for developing women managers: how well do they fulfill their objectives? Journal of Management Development, 14 (2), 39-53.

Linehan, M. \& Walsh, J.S. (1999). Mentoring relationships and the female managerial career. Career Development International, 4 (7), 348-352.

Lobel, S.A. (1993). Sexuality at work: where do we go from here? Journal of Vocational Behaviour, 42, 136-152.

Maccoby, E.E. \& Jacklin, C.N. (1974). The psychology of sex differences. Stanford, CA: Stanford University Press.

Mainiero, L.A. (1989). Office romance. New York, NY: Rawson Associates.

Makin, P., Cooper, C. \& Cox, C. (1989). Managing people at work. Leicester: The British Psychological Society.

Merriam, S.B. ( 2002). Qualitative research in practice: Examples for discussion and analysis. San Francisco, CA: Jossey-Bass.

Missirian, A.K. (1982). The corporate connection: why executive women need mentors to reach the top. Englewood Cliffs, NJ: Prentice-Hall.

Morrison, A.M.( 1988). Women in the corporation: the value added. New York: Sage.

Morrison, A.N. \& Von Glinow, M.A. (1988). Women and minorities in management. Center for Effective Organisation, University of Southern California: Monograph.

Mouton, J. \& Marais, H.C. (1992). Basic concepts in the methodology of the social sciences. Pretoria: HSRC.

Nieva, V.F. \& Gutek, B.A. (1981). Women and work: a psychological perspective. New York: Praeger.

Noe, R.A. (1986). An investigation of the determinants of successfully aligned mentoring relationships. Personnel Psychology, 421, 457-479.

Noe, R.A. (1988). Women and mentoring: a review and research agenda. Acadmey of Management Review, 13, 65-78.

Okanlawon, G. (1994). Women as strategic decision-makers: a reflection on organisational barriers. Women in Management Review, 9 (4), 25-32.

Parsloe, E. \& Wray, M. (2000). Coaching and mentoring: practical methods to improve learning. New York: Kogan Page.

Phillips-Jones, L.L. (1982). Mentors and protegés. New York, NY: Arbor House.

Powell, G.N. (1988). Women and men in management. Newbury Park, CA: Sage.

Ragins, B.R. (1989). Barriers to mentoring: the female manager's dilemma. Human Relations, 42, 1-22.

Ragins, B.R. (1995). Diversity, power and mentoring in organisations: a cultural, structural and behavioural perspective. In Chemers, M.M., Oskamp, S. \& Costanzo, M.A. (Eds). Diversity in organisations: new perspectives for a changing workplace. Thousand Oaks, CA: Sage.

Ragins, B.R. (1997). Diversified mentoring relationships in organisations. Academy of Management Review, 22 (2), 482-521.

Ragins, B.R. \& Cotton, J. (1991). Easier said than done: gender differences in perceived barriers to gaining a mentor. Academy of Management Journal, 34, 939-951.

Ragins, B.R. \& Cotton, J.L. (1996). Jumping the hurdles: barriers to mentoring for women in organisations. Leadership and Organisation Development Journal, 17 (3), 37-41.
Ragins, B.R. \& Cotton, J. (1999). Mentor functions and outcomes: a comparison of men and women in formal and informal mentoring relationships. Journal of Applied Psychology, 84 (4), 529-550.

Ragins, B.R. \& Scandura, T. (1994). Gender differences in expected outcomes of mentoring relationsihps. Academy of Management Journal, 37, 957-971.

Ragins, B.R. \& Sundstrom, E. (1989). Gender and power in organisations: a longitudinal perspective. Psychological Bulletin, 105, 51-88.

Reich, M.H. (1985). Executive views from both sides of mentoring. Personnel, 62 (3), 42-46.

Reynolds, L. (1993). New Congress will tackle women's issues. HR Focus, 70 (2), 1-3.

Robbins, S.P. (1993). Organisational behaviour (6 $6^{\text {th }}$ ed). New York, NY: Prentice-Hall.

Scandura, T.A. (1992). Mentorship and career mobility: an empirical investigation. Journal of Organisational Behaviour, $13,169-174$

Scandura, T.A. \& Hamilton, B.A. (2002). Enhancing performance through mentoring. In S. Sonnentag (Ed.). Psychological management of individual performance (pp. 293-308). New York: Wiley.

Scandura, T.A., Tejeda, M.J., Werther, W.B. \& Lankau, M.J. (1996) Perspectives on mentoring. Leadership \& Organisation Development Journal, 17 (3). 50-56.

Scandura, T.A. \& Williams, E.A. (2002). Formal mentoring: The promise and the precipice. In C.L. Cooper \& R.J. Burke (Eds.). The new world of work: Challenges and opportunities, 49-74. Oxford: Blackwell.

Schreuder, A.M.G. \& Theron, A.L. (1997). Careers: an organisational perspective. Cape Town: Juta.

Schreuder, A.M.G. \& Theron, A.L. (2001). Careers: an organisational perspective. Cape Town: Juta.

Shea, G. (1995). Can a supervisor mentor? Supervision, November, 16-19.

Sonnenfeld, J.A. \& Ward, A. (1995). Being successful at succession. Directors and Boards, 19 (4), 17-21.

Silverman, D. (2000). Doing qualitative research: A practical handbook. London: Sage.

Strauss, A. \& Corbin, J. (1990). Basics of qualitative research: grounded theory. Procedures and techniques. Newbury Park: Sage.

Stumpf, S.A. \& London, M. (1981). Management promotions: individual and organisational factors influencing the decision process. Academy of Management Review, 6, 539-549.

Tabbron, A., Macaulay, S. \& Cook, S. (1997). Making mentoring work. Training for Quality, 5 (1), 6-9.

Thomas, D.A. (2001). The truth about mentoring minorities: race matters. Harvard Business Review, 79 (4), 98-111.

Veale, D.J. \& Wachtel, J.M. (1996). Mentoring and coaching as part of a human resource development strategy: an example at Coca-Cola Foods. Leadership \& Organisation Development Journal, 17 (3), 16-20.

Webb, L.M. (1995). A proactive stance. Connections: The Southern States Communication Association Newsletter, 15 (1), 4-6.

White, B., Cox, C. \& Cooper, C. (1992). Women's career development: a study of high flyers. Cambridge: Blackwell.

Whitely, W., Dougherty, T.W. \& Dreher, G.F. (1991). Relationship of career mentoring and socioeconomic origin to managers' and professionals' early career progress. Academy of Management Journal, 34, 331-351.

Wilbur, J. (1987). Does mentoring breed success? Training and Development Journal, 41 (11), 38-41.

Wilson, J.A. \& Elman, N.S. (1990). Organisational benefits of mentoring. Academy of Management Executive, 4 (4), 88-94. 